\title{
Effects of previous episodes of influenza and vaccination in preventing laboratory-confirmed influenza in Navarre, Spain, 2013/14 season
}

J Castilla ${ }^{12}$, A Navascués ${ }^{3}$, M Fernández-Alonso ${ }^{4}$, G Reina ${ }^{4}$, E Albéniz ${ }^{5}$, F Pozo ${ }^{6}$, N Álvarez $5^{7}$, I Martínez-Baz ${ }^{12}$, M Guevara ${ }_{12}$, M García-Cenoz ${ }^{12}$, F Irisarri ${ }^{12}$, I Casado ${ }^{12}$, C Ezpeleta ${ }^{3}$, Primary Health Care Sentinel Network and Network for Influenza Surveillance in Hospitals of Navarra ${ }^{8}$

1. Instituto de Salud Pública de Navarra, IdiSNA - Navarra Institute for Health Research, Pamplona, Spain

2. CIBER Epidemiología y Salud Pública (CIBERESP), Madrid, Spain

3. Complejo Hospitalario de Navarra, IdiSNA - Navarra Institute for Health Research, Pamplona, Spain

4. Clínica Universidad de Navarra, IdiSNA - Navarra Institute for Health Research, Pamplona, Spain

5. Servicio Navarro de Salud, IdiSNA - Navarra Institute for Health Research, Pamplona, Spain

6. Centro Nacional de Microbiologia (World Health Organization National Influenza Centre Madrid), Instituto de Salud Carlos III, Majadahonda, Spain

7. Red de Investigación en Servicios de Salud en Enfermedades Crónicas (REDISSEC), Pamplona, Spain

8. The members of these networks are listed at the end of the article

Correspondence: Jesús Castilla (jcastilc@navarra.es)

Citation style for this article:

Castilla J, Navascués A, Fernández-Alonso M, Reina G, Albéniz E, Pozo F, Álvarez N, Martínez-Baz I, Guevara M, García-Cenoz M, Irisarri F, Casado I, Ezpeleta C,

Primary Health Care Sentinel Network and Network for Influenza Surveillance in Hospitals of Navarra. Effects of previous episodes of influenza and vaccination in

preventing laboratory-confirmed influenza in Navarre, Spain, 2013/14 season. Euro Surveill. 2016;21(22):pii=30243. D0I: http://dx.doi.org/10.2807/156o-7917.

ES.2016.21.22.30243

Article submitted on 27 July 2015 / accepted on 25 February 2016 / published on 02 June 2016

We estimated whether previous episodes of influenza and trivalent influenza vaccination prevented laboratory-confirmed influenza in Navarre, Spain, in season 2013/14. Patients with medically-attended influenzalike illness (MA-ILI) in hospitals $(n=645)$ and primary healthcare $(n=525)$ were included. We compared 589 influenza cases and 581 negative controls. MA-ILI related to a specific virus subtype in the previous five seasons was defined as a laboratory-confirmed influenza infection with the same virus subtype or MA-ILI during weeks when more than $25 \%$ of swabs were positive for this subtype. Persons with previous MA-ILI had $30 \%$ (95\% confidence interval $(\mathrm{CI}):-7$ to 54 ) lower risk of MA-ILI, and those with previous MA-ILI related to $\mathrm{A}\left(\mathrm{H}_{1} \mathrm{~N}_{1}\right)$ pdmog or $\mathrm{A}\left(\mathrm{H}_{3} \mathrm{~N}_{2}\right)$ virus, had a, respectively, $63 \%(95 \% \mathrm{Cl}: 16-84)$ and $65 \%(95 \% \mathrm{Cl}: 13-86)$ lower risk of new laboratory-confirmed influenza by the same subtype. Overall adjusted vaccine effectiveness in preventing laboratory-confirmed influenza was 31\% (95\% Cl: 5-50): $45 \%$ (95\% Cl: $12-65)$ for $\mathrm{A}\left(\mathrm{H}_{1} \mathrm{~N}_{1}\right)$ pdmog and $20 \%(95 \% \mathrm{Cl}:-16$ to 44$)$ for $\mathrm{A}\left(\mathrm{H}_{3} \mathrm{~N}_{2}\right)$. While a previous influenza episode induced high protection only against the same virus subtype, influenza vaccination provided low to moderate protection against all circulating subtypes. Influenza vaccine remains the main preventive option for high-risk populations.

\section{Introduction}

Influenza produces annual epidemics that spread widely in the susceptible population. About $20 \%$ of children and $5 \%$ of adults worldwide develop symptomatic influenza each year [1]. This exposure could confer immunity that would protect against the same virus type and subtype in subsequent seasons. Since the 2009 pandemic, influenza virus $A\left(\mathrm{H}_{1} \mathrm{~N}_{1}\right)$ pdmog, $A\left(\mathrm{H}_{3} \mathrm{~N}_{2}\right)$ and $B$ have been alternating, thus part of the population may have acquired natural immunity after exposure to these viruses [2].

In serological surveys, nearly all children aged nine years or older had antibodies against influenza $A$ [3]. However, this does not mean that they are totally protected against this virus type, since antigenic drift of the influenza virus allows it to escape immune control. Differences in protection could not be accounted for by differences in serum haemagglutination inhibition titres, demonstrating that multiple immune mechanisms induced by natural infection confer resistance to influenza $[4,5]$.

Annual influenza vaccination is the primary measure to prevent influenza and its consequences [1]. Trivalent seasonal influenza vaccines include strains of influenza $A\left(\mathrm{H}_{1} \mathrm{~N}_{1}\right), A\left(\mathrm{H}_{3} \mathrm{~N}_{2}\right)$ and $B$. In the $2013 / 14$ season, the influenza vaccine composition recommended in the northern hemisphere included an A/California/7/2009(H1N1)pdmog-like virus, an $A\left(\mathrm{H}_{3} \mathrm{~N}_{2}\right)$ virus antigenically similar to the cell-propagated prototype virus A/Victoria/361/2011, and a B/ Massachusetts/2/2011-like virus [6]. 
Weekly incidence of patients with medically attended influenza-like illness and number of swabbed patients by test result, Navarre, Spain, influenza season $2013 / 14(n=1,170$ in the study period )

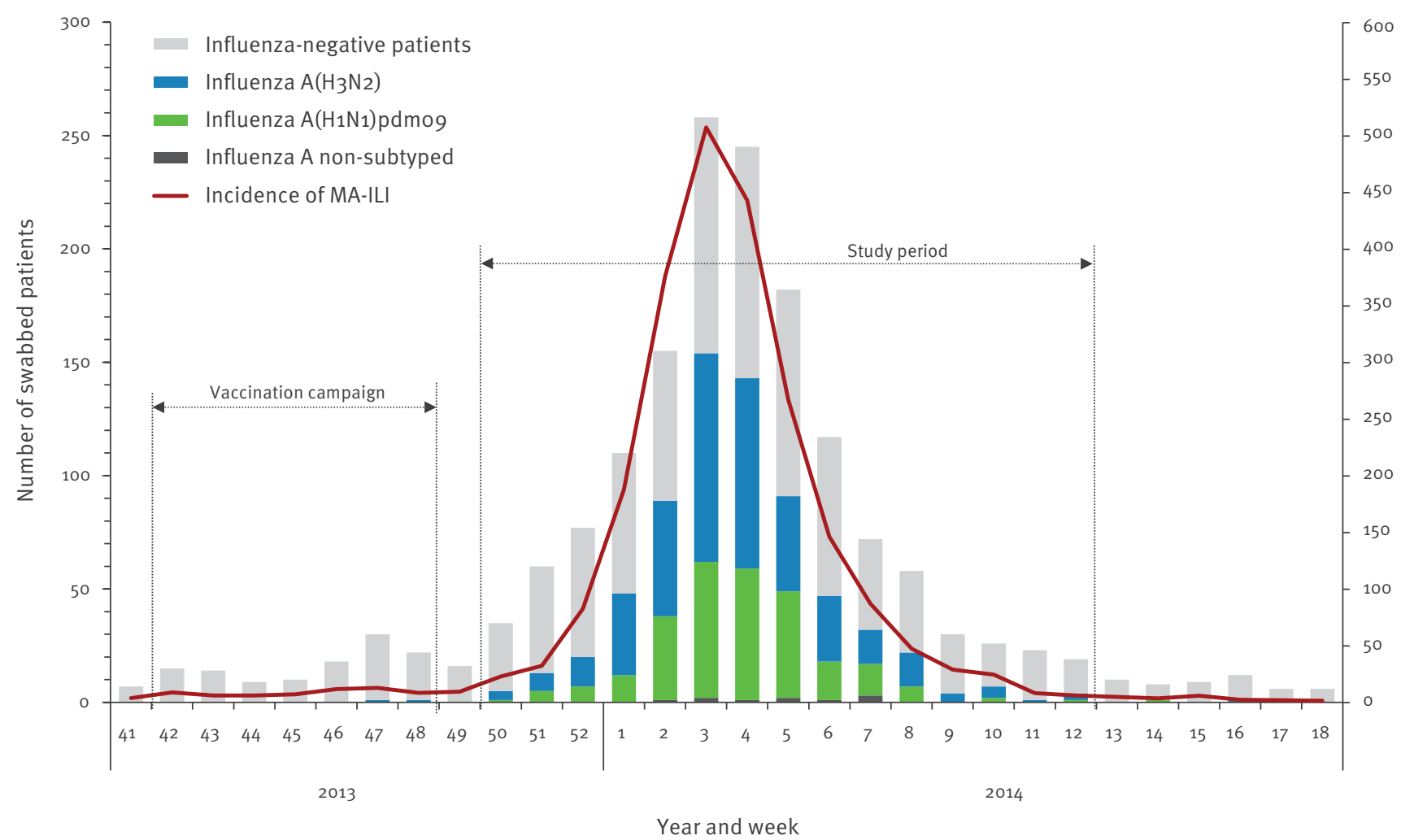

MA-ILI: medically attended influenza-like illness.

During the $2013 / 14$ season, influenza $A\left(\mathrm{H}_{1} \mathrm{~N}_{1}\right)$ pdmog and $\mathrm{A}\left(\mathrm{H}_{3} \mathrm{~N}_{2}\right)$ viruses co-circulated in Spain and the rest of Europe, and most characterised isolates were A/StPetersburg/27/2011( $\left.\mathrm{H}_{1} \mathrm{~N}_{1}\right)$ pdmog-like and $\mathrm{A} /$ Texas/50/2012(H3N2)-like [7-9].

Although both natural infection and vaccination with inactivated vaccine stimulate serum haemagglutination inhibition antibodies and provide protection against homologous wild-type influenza strains, the protection associated with natural infection lasts longer and is broader than that induced by inactivated vaccine $[10,11]$. However, the effect of natural immunity and its practical relevance are not generally evaluated. The aim of this study was to estimate the effects of previous influenza episodes and of the trivalent vaccine in preventing inpatient and outpatient cases with laboratory-confirmed influenza in Navarre, Spain, in the $2013 / 14$ season.

\section{Methods}

\section{Study population}

This study was performed in the region of Navarre, Spain. The Regional Health Service provides healthcare, free at point of service, to $97 \%$ of the population.
The Navarre Ethical Committee for Medical Research approved the study protocol.

The seasonal vaccination campaign took place from 14 October to 30 November 2013. The trivalent inactivated split non-adjuvanted vaccine was recommended and offered free of charge to people aged 60 years or older and to those with risk factors or major chronic conditions [12]. Other people were also vaccinated if they paid for the vaccine.

In the 2013/14 season and the preceding seasons, influenza surveillance was based on automatic reporting of cases of medically-attended influenza-like illness (MA-ILI) from all primary healthcare centres and hospitals. ILI was considered to be the sudden onset of any general symptom (fever or feverishness, malaise, headache or myalgia) and any respiratory symptom (cough, sore throat or shortness of breath). In addition, a sentinel network composed of a representative sample of primary healthcare physicians, covering $16 \%$ of the Navarre population, was asked to take double 
Predominant circulating influenza virus strains in Navarre, Spain, in the season analysed (2013/14) and the five previous seasons (2008/09-2012/13)

\begin{tabular}{|c|c|c|c|c|}
\hline $\begin{array}{l}\text { Influenza } \\
\text { season }\end{array}$ & $\begin{array}{l}\text { Predominant influenza } \\
\text { type/subtype }\end{array}$ & Predominant genotype & $\begin{array}{l}\text { Periods when more than } 25 \% \text { of } \\
\text { patients tested positive to the } \\
\text { predominant virus type/subtype }\end{array}$ & $\begin{array}{l}\text { Proportion of } \\
\text { positive swabs }\end{array}$ \\
\hline $2008 / 09$ & $\mathrm{~A}\left(\mathrm{H}_{3} \mathrm{~N}_{2}\right)$ & A/Brisbane/10/2007 $\left(\mathrm{H}_{3} \mathrm{~N}_{2}\right)$ & 16 Nov $2008-1$ Feb 2009 & $70 \%$ \\
\hline $2009 / 10$ & $\mathrm{~A}\left(\mathrm{H}_{1} \mathrm{~N}_{1}\right) \mathrm{pdmog}$ & A/California/7/2009( $\left.\mathrm{H}_{1} \mathrm{~N}_{1}\right)$ & $\begin{array}{l}28 \text { Jun } 2009-9 \text { Sep } 2009 \\
4 \text { Oct } 2009-20 \text { Dec } 2009\end{array}$ & $51 \%$ \\
\hline 2010/11 & $\mathrm{A}\left(\mathrm{H}_{1} \mathrm{~N}_{1}\right) \mathrm{pdmog}$ & A/California/07/2009(H1N1) & 21 Nov $2010-13$ Feb 2011 & $59 \%$ \\
\hline 2011/12 & $\mathrm{A}\left(\mathrm{H}_{3} \mathrm{~N}_{2}\right)$ & $\begin{array}{c}\text { A/Victoria/361/2011 }\left(\mathrm{H}_{3} \mathrm{~N}_{2}\right) \\
\left.\text { A/England/259/2011( } \mathrm{H}_{3} \mathrm{~N}_{2}\right) \\
\text { A/lowa/19/2010(H3N2) } \\
\end{array}$ & 23 Dec 2011 - 11 Mar 2012 & $67 \%$ \\
\hline $2012 / 13$ & B & $\begin{array}{c}\text { B/Estonia/55669/2011 } \\
\text { B/Wisconsin/1/2010 }\end{array}$ & 31 Dec $2012-7$ Apr 2013 & $64 \%$ \\
\hline $2013 / 14$ & $\begin{array}{c}\mathrm{A}\left(\mathrm{H}_{3} \mathrm{~N}_{2}\right) \\
\mathrm{A}\left(\mathrm{H}_{1} \mathrm{~N}_{1}\right) \text { pdmo9 }\end{array}$ & $\begin{array}{c}\left.\text { A/Texas/50/2012( } \mathrm{H}_{3} \mathrm{~N}_{2}\right) \\
\left.\text { A/StPetersburg/27/2011( } \mathrm{H}_{1} \mathrm{~N}_{1}\right)\end{array}$ & 9 Dec $2013-23$ Mar 2014 & $50 \%$ \\
\hline
\end{tabular}

swabs, nasopharyngeal and pharyngeal, after obtaining verbal informed consent, from all their patients diagnosed with ILI whose symptoms had begun less than five days before the consultation. The protocol for influenza cases in hospitals foresees nasopharyngeal and pharyngeal swabbing of all hospitalised patients with ILI.

Swabs were analysed by real-time RT-PCR, using either of two commercial real-time RT-PCR assays: RealCycler FLURSV (Progenie Molecular, Spain) and Real Time Ready Influenza $\mathrm{A}\left(\mathrm{H}_{1} \mathrm{~N}_{1}\right)$ Detection Set (Roche Diagnostics, Switzerland). Detection of influenza $A$ and $B$ was based on the matrix protein gene and subtyping was based on the haemagglutinin (HA) gene. The internal amplification control was positive in all influenza-negative samples, indicating that failure to detect influenza virus was not due to inhibition.

Strains systematically selected among culture-positive samples by week and virus type/subtype were sent to the National Influenza Centre laboratory in Madrid for genetic characterisation based on partial sequencing of the HA gene (subunit HA1).

\section{Study design and statistical analysis}

We carried out a test-negative case-control study in the population covered by the Navarre Health Service. Healthcare workers, persons living in nursing homes and children under six months of age were excluded. The study included the consecutive weeks in which influenza virus was detected, i.e. the period from 9 December 2013 (week 50) to 23 March 2014 (week 12). All information related to patients was linked using a unique identification number.

The cases were MA-ILI patients in primary healthcare or in hospitals for whom influenza virus infection was confirmed by RT-PCR, and the controls were MA-ILI patients who tested negative for influenza virus. Their vaccination status for the trivalent seasonal influenza vaccine was obtained from the regional vaccination register [13]. Subjects were considered to be protected starting 14 days after vaccine administration.

From the electronic records of epidemiological and virological surveillance we obtained information on MA-ILI diagnosis and RT-PCR-positive patients in previous seasons for the study subjects. We defined previous MA-ILI related to a specific virus subtype as a laboratory-confirmed influenza infection with this virus subtype (virological criterion) that had occurred in the seasons from 2008/09 through $2012 / 13$ or as MA-ILI that occurred in these seasons in weeks where more than $25 \%$ of swabs were confirmed for this influenza virus subtype (epidemiological criterion). Five previous seasons were considered given the long-lived protection associated with natural infection $[10,11]$ and because no major shift had affected the circulating viruses involved in the analysis. Table 1 shows the periods when more than $25 \%$ of patients tested positive to the predominant virus type/subtype and the average percentage of swabbed patients who tested positive for the predominant circulating influenza virus by season. Finally, previous MA-ILI related to any influenza virus included all laboratory-confirmed influenza cases or MA-ILI patients that had occurred in the seasons 2008/og through 2012/13 in weeks with more than $25 \%$ of swabs confirmed for any influenza virus, although on average $64 \%$ of swabbed patients tested positive for any influenza virus during these periods.

Percentages were compared by chi-square test. The odds of influenza vaccination and the odds of MA-ILI in the previous five seasons were compared between cases and controls. Logistic regression was used to calculate the odds ratios (OR) with their $95 \%$ confidence intervals $(\mathrm{Cl})$, adjusting for sex, age group $(45,5-14$, $15-44,45-64$ and $\geq 65$ years), major chronic conditions (heart disease, respiratory disease, renal disease, 


\section{TABLE 2}

Characteristics of patients with medically-attended influenza-like illness included in the test negative case-control analysis, by test result, Navarre, Spain, 2013/14 season $(n=1,170)$

\begin{tabular}{|c|c|c|c|c|c|c|c|c|c|c|}
\hline & \multicolumn{2}{|c|}{ Test-negative controls } & \multicolumn{2}{|c|}{ Influenza cases ${ }^{\mathrm{a}}$} & \multirow{2}{*}{$p$ value } & \multicolumn{2}{|c|}{$\mathrm{A}\left(\mathrm{H}_{1} \mathrm{~N}_{1}\right) \mathrm{pdmog}$} & \multicolumn{2}{|c|}{$\mathrm{A}\left(\mathrm{H}_{3} \mathrm{~N}_{2}\right)$} & \multirow{2}{*}{$\mathrm{p}$ value } \\
\hline & $n$ & $\%$ & $\mathrm{n}$ & $\%$ & & $\mathrm{n}$ & $\%$ & $\mathrm{n}$ & $\%$ & \\
\hline \multicolumn{5}{|l|}{ Age groups (years) } & $<0.001$ & & & & & $<0.001$ \\
\hline$<5$ & 108 & 19 & 29 & 5 & & 13 & 6 & 16 & 5 & \\
\hline 5-14 & 36 & 6 & 34 & 6 & & 16 & 7 & 18 & 5 & \\
\hline $15-44$ & 125 & 22 & 196 & 33 & & 84 & 36 & 111 & 32 & \\
\hline $45-64$ & 108 & 19 & 163 & 28 & & 80 & 34 & 81 & 23 & \\
\hline$\geq 65$ & 204 & 35 & 167 & 28 & & 42 & 18 & 123 & 35 & \\
\hline \multicolumn{5}{|l|}{ Sex } & 0.295 & & & & & 0.754 \\
\hline Male & 290 & 50 & 312 & 53 & & 127 & 54 & 184 & 53 & \\
\hline Female & 291 & 50 & 277 & 47 & & 108 & 46 & 165 & 47 & \\
\hline \multicolumn{5}{|c|}{ Month of sample collection } & $<0.001$ & & & & & 0.508 \\
\hline December & 99 & 17 & 49 & 8 & & 15 & 6 & 34 & 10 & \\
\hline January & 306 & 53 & 435 & 74 & & 179 & 76 & 253 & 72 & \\
\hline February & 140 & 24 & 96 & 16 & & 38 & 16 & 56 & 16 & \\
\hline March & 36 & 6 & 9 & 2 & & 3 & 1 & 6 & 2 & \\
\hline \multicolumn{5}{|l|}{ Residence } & 0.933 & & & & & 0.970 \\
\hline Rural & 167 & 29 & 168 & 29 & & 67 & 29 & 99 & 28 & \\
\hline Urban & 414 & 71 & 421 & 71 & & 168 & 71 & 250 & 72 & \\
\hline \multicolumn{5}{|l|}{ Major chronic conditions } & 0.116 & & & & & 0.021 \\
\hline No & 285 & 49 & 316 & 54 & & 140 & 60 & 174 & 50 & \\
\hline Yes & 296 & 51 & 273 & 46 & & 95 & 40 & 175 & 50 & \\
\hline \multicolumn{5}{|l|}{ Healthcare setting ${ }^{b}$} & $<0.001$ & & & & & 0.969 \\
\hline Primary healthcare & 182 & 31 & 345 & 59 & & 139 & 59 & 205 & 59 & \\
\hline Hospital & 400 & 69 & 245 & 42 & & 97 & 41 & 144 & 41 & \\
\hline \multicolumn{5}{|c|}{ Seasonal influenza vaccine $2013 / 14$} & $<0.001$ & & & & & 0.001 \\
\hline No & 383 & 66 & 445 & 76 & & 195 & 83 & 246 & 70 & \\
\hline Yes & 198 & 34 & 144 & 24 & & 40 & 17 & 103 & 30 & \\
\hline \multicolumn{5}{|c|}{ Seasonal influenza vaccine $2012 / 13$} & 0.006 & & & & & 0.003 \\
\hline No & 395 & 68 & 443 & 75 & & 192 & 82 & 247 & 71 & \\
\hline Yes & 186 & 32 & 146 & 25 & & 43 & 18 & 102 & 29 & \\
\hline \multicolumn{5}{|l|}{ Previous MA-ILI ${ }^{\mathrm{C}}$} & 0.251 & & & & & 0.631 \\
\hline No & 523 & 90 & 527 & 89 & & 208 & 89 & 314 & 90 & \\
\hline Virological criteria & 13 & 2 & 7 & 1 & & 4 & 2 & 3 & 1 & \\
\hline Epidemiological criteria & 45 & 8 & 55 & 9 & & 23 & 10 & 32 & 9 & \\
\hline \multicolumn{5}{|c|}{ Previous MA-ILI related to $\mathrm{A}\left(\mathrm{H}_{1} \mathrm{~N}_{1}\right) \mathrm{pdmog}^{c}$} & 0.487 & & & & & 0.240 \\
\hline No & 546 & 94 & 559 & 95 & & 226 & 96 & 328 & 94 & \\
\hline Yes & 35 & 6 & 30 & 5 & & 9 & 4 & 21 & 6 & \\
\hline \multicolumn{5}{|c|}{ Previous MA-ILI related to $A\left(\mathrm{H}_{3} \mathrm{~N}_{2}\right)^{c}$} & 0.719 & & & & & 0.022 \\
\hline No & 559 & 96 & 569 & 97 & & 222 & 94 & 342 & 98 & \\
\hline Yes & 22 & 4 & 20 & 3 & & 13 & 6 & 7 & 2 & \\
\hline Total & 581 & 100 & 589 & 100 & & 235 & 100 & 349 & 100 & \\
\hline
\end{tabular}

MA-ILI: medically attended influenza-like illness.

a Includes seven cases of not subtyped influenza A. Two patients had simultaneous positive test results for influenza $A\left(\mathrm{H}_{1} \mathrm{~N}_{1}\right) \mathrm{pdmog}$ and influenza $A\left(\mathrm{H}_{3} \mathrm{~N}_{2}\right)$.

${ }^{\mathrm{b}}$ Two patients were attended in primary healthcare and referred to hospital.

c Medically-attended influenza-like illness virologically or epidemiologically related to influenza in the previous five seasons. 
Characteristics of patients with medically-attended influenza-like illness, by previous influenza diagnosis and influenza vaccination status, Navarre, Spain, 2013/14 season $(n=1,170)$

\begin{tabular}{|c|c|c|c|c|c|c|c|}
\hline & \multirow{2}{*}{$\begin{array}{c}\text { Total tested } \\
\mathrm{n}\end{array}$} & \multicolumn{2}{|c|}{ Previous MA-ILIa } & \multirow{2}{*}{$p$ value } & \multicolumn{2}{|c|}{ Influenza vaccination } & \multirow{2}{*}{$\mathrm{p}$ value } \\
\hline & & $\mathrm{n}$ & $\%$ & & $\mathrm{n}$ & $\%$ & \\
\hline \multicolumn{4}{|l|}{ Age groups (years) } & $<0.001$ & & & $<0.001$ \\
\hline$<5$ & 137 & 5 & 4 & & 15 & 11 & \\
\hline 5-14 & 70 & 25 & 36 & & 9 & 13 & \\
\hline $15-44$ & 321 & 53 & 17 & & 28 & 9 & \\
\hline $45-64$ & 271 & 24 & 9 & & 53 & 20 & \\
\hline$\geq 65$ & 371 & 13 & 4 & & 237 & 64 & \\
\hline \multicolumn{4}{|l|}{ Sex } & 0.597 & & & 0.249 \\
\hline Male & 602 & 59 & 10 & & 167 & 28 & \\
\hline Female & 568 & 61 & 11 & & 175 & 31 & \\
\hline \multicolumn{4}{|l|}{ Residence } & 0.939 & & & 0.896 \\
\hline Rural & 835 & 86 & 10 & & 245 & 29 & \\
\hline Urban & 335 & 34 & 10 & & 97 & 29 & \\
\hline \multicolumn{4}{|c|}{ Major chronic conditions } & 0.046 & & & $<0.001$ \\
\hline No & 601 & 72 & 12 & & 72 & 12 & \\
\hline Yes & 569 & 48 & 8 & & 270 & 47 & \\
\hline \multicolumn{4}{|l|}{ Healthcare setting a } & $<0.001$ & & & $<0.001$ \\
\hline Primary healthcare & 527 & 88 & 17 & & 74 & 14 & \\
\hline Hospital & 645 & 32 & 5 & & 269 & 42 & \\
\hline \multicolumn{4}{|l|}{ Previous MA-ILI ${ }^{b}$} & NA & & & 0.001 \\
\hline No & 1,050 & 0 & 0 & & 322 & 31 & \\
\hline Yes & 120 & 120 & 100 & & 20 & 17 & \\
\hline Total & 1,170 & 120 & 10 & & 342 & 29 & \\
\hline
\end{tabular}

MA-ILI: medically attended influenza-like illness; NA: not applicable.

a Two patients were attended in primary healthcare and referred to hospital.

${ }^{b}$ Medically-attended influenza-like illness virologically or epidemiologically related to any influenza virus in the previous five seasons.

cancer, diabetes mellitus, liver cirrhosis, dementia, stroke, immunodeficiency, rheumatic disease and body mass index $\left.\geq 40 \mathrm{~kg} / \mathrm{m}^{2}\right)$, month of sample collection and healthcare setting (primary healthcare and hospital). Separate analyses were done by type/subtype of influenza, age group and healthcare setting. The fraction of prevented disease in exposed individuals or vaccine effectiveness (VE) was estimated as (1-OR) x 100.

\section{Results}

During the 2013/14 season in Navarre, the incidence of MA-ILI, the number of swabbed patients and the number of influenza-positive cases followed similar trends, peaking in week 3 of 2014 (Figure).

In the study period, a total of 1,170 MA-ILI patients were swabbed, of whom 525 were attended in primary healthcare and 645 were hospitalised. A total of 589 (50\%) were confirmed for influenza virus, all of them for influenza A. Influenza $\mathrm{A}\left(\mathrm{H}_{3} \mathrm{~N}_{2}\right)$ virus was detected in 349 cases, influenza $A\left(\mathrm{H}_{1} \mathrm{~N}_{1}\right)$ pdmog in 235 , and seven remained non-subtyped. Two patients had a simultaneous positive test result for influenza $A\left(\mathrm{H}_{1} \mathrm{~N}_{1}\right)$ pdmog and $A\left(H_{3} N_{2}\right)$. Sequence analysis of the amplification product (the $\mathrm{HA}_{1}$ fragment of the haemagglutinin gene) was available for 114 influenza viruses. All $42 \mathrm{~A}\left(\mathrm{H}_{1} \mathrm{~N}_{1}\right)$ pdmo9 viruses were $A / S t P e t e r s b u r g / 27 / 2011$-like and all $72 \mathrm{~A}\left(\mathrm{H}_{3} \mathrm{~N}_{2}\right)$ viruses were $A /$ Texas/50/2012-like.

Compared with the test-negative controls $(n=581)$, confirmed cases of influenza were more frequent among 15 to 64 years-olds (61\% vs $40 \%$; $p<0.001$ ) and those attended in primary healthcare ( $58 \%$ vs $31 \%$; $p<0.001)$. Compared with influenza $\mathrm{A}\left(\mathrm{H}_{1} \mathrm{~N}_{1}\right)$ pdmo9, influenza $\mathrm{A}\left(\mathrm{H}_{3} \mathrm{~N}_{2}\right)$ was more frequently detected in persons 65 years or older ( $35 \%$ vs $18 \%$; $p<0.001$ ) and in persons with major chronic conditions ( $50 \%$ vs $40 \%$; $p=0.021$ ). The proportion of hospitalised patients was the same for both influenza $A\left(\mathrm{H}_{1} \mathrm{~N}_{1}\right)$ pdmog and $\mathrm{A}\left(\mathrm{H}_{3} \mathrm{~N}_{2}\right)$ cases (41\% vs 41\%; $p=0.970$ ) (Table 2 ).

A similar proportion of laboratory-confirmed cases and influenza-negative controls had had MA-ILI in the previous five seasons ( $11 \%$ vs $10 \% ; p=0.759$ ), but only $17 \%$ of them (20/120) had been laboratory-confirmed for influenza virus in the previous episode. Of the 120 patients who had had any MA-ILI episode in the previous five years, 18 had had more than one episode and only one had had two episodes related to the same virus subtype. Among the 589 cases, 144 (24\%) had 


\section{TABLE 4A}

Preventive effect of previous episodes of medically-attended influenza-like illness and of the trivalent inactivated influenza vaccine against new cases of laboratory-confirmed influenza in Navarre, Spain, 2013/14 season $(n=1,170)$

\begin{tabular}{|c|c|c|c|c|c|}
\hline & Cases; controls & $\begin{array}{c}\text { Crude prevented } \\
\text { fraction } \\
\%(95 \% \mathrm{Cl})\end{array}$ & $\mathrm{p}$ value & $\begin{array}{c}\text { Adjusted prevented } \\
\text { fraction } \\
\%(95 \% \mathrm{Cl})^{\mathrm{a}}\end{array}$ & $\mathrm{p}$ value \\
\hline \multicolumn{6}{|c|}{ All influenza cases vs controls } \\
\hline Previous MA-ILI related to any influenzab & $62 ; 58$ & $\begin{array}{c}-6 \\
(-55 \text { to } 27) \\
\end{array}$ & 0.759 & $\begin{array}{c}30 \\
(-7 \text { to } 54) \\
\end{array}$ & 0.098 \\
\hline Vaccinated & $144 ; 198$ & $\begin{array}{c}37 \\
\text { (19 to 51) } \\
\end{array}$ & $<0.001$ & $\begin{array}{c}31 \\
\text { (5 to 50) } \\
\end{array}$ & 0.023 \\
\hline Age $<65$ years & $422 ; 377$ & & & & \\
\hline Previous MA-ILI related to any influenzab & $56 ; 51$ & $\begin{array}{c}2 \\
(-47 \text { to } 35) \\
\end{array}$ & 0.915 & $\begin{array}{c}32 \\
(-9 \text { to } 57) \\
\end{array}$ & 0.107 \\
\hline Vaccinated & $44 ; 61$ & $\begin{array}{c}40 \\
\text { (9 to } 60)\end{array}$ & 0.017 & $\begin{array}{c}35 \\
(-5 \text { to } 60)\end{array}$ & 0.081 \\
\hline Age $\geq 65$ years & $167 ; 204$ & & & & \\
\hline Previous MA-ILI related to any influenzab & $6 ; 7$ & $\begin{array}{c}-5 \\
(-218 \text { to 65) }\end{array}$ & 0.933 & $\begin{array}{c}21 \\
(-153 \text { to } 75) \\
\end{array}$ & 0.694 \\
\hline Vaccinated & $100 ; 137$ & $\begin{array}{c}27 \\
(-12 \text { to } 52) \\
\end{array}$ & 0.147 & $\begin{array}{c}28 \\
(-11 \text { to } 54) \\
\end{array}$ & 0.139 \\
\hline Primary healthcare patients ${ }^{c}$ & $345 ; 182$ & & & & \\
\hline Previous MA-ILI related to any influenza ${ }^{b}$ & $52 ; 36$ & $\begin{array}{c}28 \\
(-15 \text { to } 55) \\
\end{array}$ & 0.169 & $\begin{array}{c}34 \\
(-9 \text { to } 60) \\
\end{array}$ & 0.103 \\
\hline Vaccinated & $47 ; 27$ & $\begin{array}{c}9 \\
(-51 \text { to } 46)\end{array}$ & 0.703 & $\begin{array}{c}21 \\
(-45 \text { to } 57)\end{array}$ & 0.452 \\
\hline Hospitalised patients ${ }^{c}$ & $245 ; 400$ & & & & \\
\hline Previous MA-ILI related to any influenza ${ }^{b}$ & $10 ; 22$ & $\begin{array}{c}27 \\
(-57 \text { to } 66) \\
\end{array}$ & 0.422 & $\begin{array}{c}21 \\
(-82 \text { to } 65) \\
\end{array}$ & 0.585 \\
\hline Vaccinated & $97 ; 172$ & $\begin{array}{c}13 \\
(-20 \text { to } 37)\end{array}$ & 0.394 & $\begin{array}{c}35 \\
\text { (4 to } 56) \\
\end{array}$ & 0.030 \\
\hline \multicolumn{6}{|c|}{ Influenza $\mathrm{A}\left(\mathrm{H}_{1} \mathrm{~N}_{1}\right)$ pdmog cases vs controls } \\
\hline All swabbed patients & $235 ; 581$ & & & & \\
\hline Previous MA-ILI related to $\mathrm{A}\left(\mathrm{H}_{1} \mathrm{~N}_{1}\right) \mathrm{pdmog}^{\mathrm{b}}$ & $9 ; 35$ & $\begin{array}{c}38 \\
(-31 \text { to } 71) \\
\end{array}$ & 0.213 & $\begin{array}{c}63 \\
(16 \text { to } 84) \\
\end{array}$ & 0.017 \\
\hline Age $<65$ years & $193 ; 377$ & & & & \\
\hline Previous MA-ILI related to $\mathrm{A}\left(\mathrm{H}_{1} \mathrm{~N}_{1}\right) \mathrm{pdmog}^{\mathrm{b}}$ & $6 ; 33$ & $\begin{array}{c}67 \\
\text { (19 to 86) } \\
\end{array}$ & 0.016 & $\begin{array}{c}78 \\
\text { (43 to 91) }\end{array}$ & 0.002 \\
\hline Vaccinated & $16 ; 61$ & $\begin{array}{c}53 \\
\text { (16 to } 74) \\
\end{array}$ & 0.010 & $\begin{array}{c}52 \\
(8 \text { to } 75) \\
\end{array}$ & 0.028 \\
\hline Age $\geq 65$ years & 42; 204 & & & & \\
\hline Previous MA-ILI related to $\mathrm{A}\left(\mathrm{H}_{1} \mathrm{~N}_{1}\right) \mathrm{pdmog}^{\mathrm{b}}$ & $3 ; 2$ & $\begin{array}{c}-677 \\
(-4,700 \text { to }-26) \\
\end{array}$ & 0.027 & $\begin{array}{c}-613 \\
(-4,470 \text { to }-11) \\
\end{array}$ & 0.038 \\
\hline Vaccinated & $24 ; 137$ & $\begin{array}{c}35 \\
(-28 \text { to } 67) \\
\end{array}$ & 0.216 & $\begin{array}{c}37 \\
(-27 \text { to } 69) \\
\end{array}$ & 0.193 \\
\hline Primary healthcare patients ${ }^{c}$ & $139 ; 181$ & & & & \\
\hline Previous MA-ILI related to $\mathrm{A}\left(\mathrm{H}_{1} \mathrm{~N}_{1}\right) \mathrm{pdmog}^{\mathrm{b}}$ & $7 ; 24$ & $\begin{array}{c}65 \\
\text { (16 to 85) } \\
\end{array}$ & 0.018 & $\begin{array}{c}70 \\
\text { (26 to 88) } \\
\end{array}$ & 0.010 \\
\hline Vaccinated & $13 ; 27$ & $\begin{array}{c}41 \\
(-20 \text { to } 71) \\
\end{array}$ & 0.144 & $\begin{array}{c}43 \\
(-28 \text { to } 75) \\
\end{array}$ & 0.171 \\
\hline Hospitalised patientsc & $97 ; 400$ & & & & \\
\hline Previous MA-ILI related to $\mathrm{A}\left(\mathrm{H}_{1} \mathrm{~N}_{1}\right) \mathrm{pdm} 9^{\mathrm{b}}$ & $2 ; 11$ & $\begin{array}{c}25 \\
(-242 \text { to } 84) \\
\end{array}$ & 0.704 & $\begin{array}{c}-6 \\
(-427 \text { to } 79) \\
\end{array}$ & 0.944 \\
\hline Vaccinated & $27 ; 172$ & $\begin{array}{c}49 \\
(17 \text { to } 69) \\
\end{array}$ & 0.007 & $\begin{array}{c}45 \\
\text { (1 to 69) }\end{array}$ & 0.047 \\
\hline
\end{tabular}

CI: confidence interval; MA-ILI: medically attended influenza-like illness.

a Results obtained from a logistic regression model adjusted for sex, age group $(<5,5-14,15-44,45-64$ and $\geq 65$ years), month of sample collection, major chronic conditions, healthcare setting (primary healthcare and hospital), medically-attended influenza-like illness virologically or epidemiologically related to the analysed influenza virus in the previous five seasons, and 2013/14 influenza vaccine.

b Medically-attended influenza-like illness virologically or epidemiologically related to influenza in the previous five seasons.

c Patients attended in primary healthcare and referred to hospital were included in both subanalyses. 
Preventive effect of previous episodes of medically-attended influenza-like illness and of the trivalent inactivated influenza vaccine against new cases of laboratory-confirmed influenza in Navarre, Spain, 2013/14 season $(n=1,170)$

\begin{tabular}{|c|c|c|c|c|c|}
\hline & Cases; controls & $\begin{array}{c}\text { Crude prevented } \\
\text { fraction } \\
\%(95 \% \mathrm{Cl})\end{array}$ & $\mathrm{p}$ value & $\begin{array}{c}\text { Adjusted prevented } \\
\text { fraction } \\
\%(95 \% \mathrm{Cl})^{\mathrm{a}}\end{array}$ & $\mathrm{p}$ value \\
\hline \multicolumn{6}{|c|}{ All influenza cases vs controls } \\
\hline \multicolumn{6}{|c|}{ Influenza $\mathrm{A}\left(\mathrm{H}_{3} \mathrm{~N}_{2}\right)$ cases vs controls } \\
\hline All swabbed patients & $349 ; 581$ & & & & \\
\hline Previous MA-ILI related to $A\left(\mathrm{H}_{3} \mathrm{~N}_{2}\right)^{\mathrm{b}}$ & $7 ; 22$ & $\begin{array}{c}48 \\
(-23 \text { to } 78)\end{array}$ & 0.137 & $\begin{array}{c}65 \\
\text { (13 to 86) }\end{array}$ & 0.024 \\
\hline Vaccinated & $103 ; 198$ & $\begin{array}{c}19 \\
\text { (-8 to 39) }\end{array}$ & 0.150 & $\begin{array}{c}20 \\
(-15 \text { to } 45)\end{array}$ & 0.228 \\
\hline Age $<65$ years & $226 ; 377$ & & & & \\
\hline Previous MA-ILI related to $A\left(\mathrm{H}_{3} \mathrm{~N}_{2}\right)^{\mathrm{b}}$ & $5 ; 19$ & $\begin{array}{c}57 \\
(-16 \text { to } 84)\end{array}$ & 0.095 & $\begin{array}{c}70 \\
\text { (15 to 90) }\end{array}$ & 0.024 \\
\hline Vaccinated & $28 ; 61$ & $\begin{array}{c}27 \\
(-19 \text { to } 55)\end{array}$ & 0.205 & $\begin{array}{c}9 \\
(-59 \text { to } 48)\end{array}$ & 0.727 \\
\hline Age $\geq 65$ years & $123 ; 204$ & & & & \\
\hline Previous MA-ILI related to $A\left(\mathrm{H}_{3} \mathrm{~N}_{2}\right)^{b}$ & $2 ; 3$ & $\begin{array}{c}-11 \\
(-573 \text { to } 82)\end{array}$ & 0.911 & $\begin{array}{c}29 \\
(-400 \text { to } 90)\end{array}$ & 0.731 \\
\hline Vaccinated & $75 ; 137$ & $\begin{array}{c}24 \\
(-22 \text { to } 52)\end{array}$ & 0.257 & $\begin{array}{c}24 \\
(-24 \text { to } 53)\end{array}$ & 0.269 \\
\hline Primary healthcare patients ${ }^{c}$ & $205 ; 182$ & & & & \\
\hline Previous MA-ILI related to $A\left(\mathrm{H}_{3} \mathrm{~N}_{2}\right)^{\mathrm{b}}$ & $6 ; 14$ & $\begin{array}{c}64 \\
\text { (7 to } 86)\end{array}$ & 0.042 & $\begin{array}{c}64 \\
(-1 \text { to } 87) \\
\end{array}$ & 0.051 \\
\hline Vaccinated & $34 ; 27$ & $\begin{array}{c}-14 \\
(-99 \text { to } 34)\end{array}$ & 0.637 & $\begin{array}{c}0 \\
(-94 \text { to } 48)\end{array}$ & 0.995 \\
\hline Hospitalised patients ${ }^{c}$ & $144 ; 400$ & & & & \\
\hline Previous MA-ILI related to $A\left(\mathrm{H}_{3} \mathrm{~N}_{2}\right)^{\mathrm{b}}$ & $1 ; 8$ & $\begin{array}{c}66 \\
(-176 \text { to } 96)\end{array}$ & 0.315 & $\begin{array}{c}65 \\
(-198 \text { to } 96) \\
\end{array}$ & 0.334 \\
\hline Vaccinated & $69 ; 172$ & $\begin{array}{c}-22 \\
(-79 \text { to } 17)\end{array}$ & 0.309 & $\begin{array}{c}28 \\
(-14 \text { to } 54)\end{array}$ & 0.159 \\
\hline
\end{tabular}

$\mathrm{Cl}$ : confidence interval; MA-ILI: medically attended influenza-like illness.

a Results obtained from a logistic regression model adjusted for sex, age group $(<5,5-14,15-44,45-64$ and $\geq 65$ years $)$, month of sample collection, major chronic conditions, healthcare setting (primary healthcare and hospital), medically-attended influenza-like illness virologically or epidemiologically related to the analysed influenza virus in the previous five seasons, and $2013 / 14$ influenza vaccine.

b Medically-attended influenza-like illness virologically or epidemiologically related to influenza in the previous five seasons.

c Patients attended in primary healthcare and referred to hospital were included in both subanalyses.

received the $2013 / 14$ seasonal vaccine, vs 198 (34\%) of the 581 controls $(p<0.001)$ (Table 2$)$.

The proportion of patients vaccinated in the current season was lower among those with previous MA-ILI than in those without a history of MA-ILI ( $17 \%$ vs $31 \%$; $p=0.001$ ). While previous MA-ILI was more frequent in patients between five and 44 years-old, in those without major chronic conditions and in those attended in primary healthcare, vaccination in the current season was more frequent in patients 65 years and older, in those with major chronic conditions and in patients attended in hospitals (Table 3).

In the analysis adjusted by influenza vaccination and other potential confounders, previous MA-ILI related to any influenza virus showed a $30 \%(95 \% \mathrm{Cl}:-7$ to 54$)$ protection against a new episode of laboratory-confirmed influenza, although this did not reach statistical significance. The overall adjusted estimate of the influenza VE was $31 \%(95 \% \mathrm{Cl}: 5-50)$. The estimate of the VE was $21 \%(95 \% \mathrm{Cl}:-45$ to 57$)$ in the analysis restricted to primary healthcare patients, and $35 \%$ (95\% Cl: 4-56) in hospitalised patients (Table 4).

In the comparison between influenza $A\left(\mathrm{H}_{1} \mathrm{~N}_{1}\right)$ pdmog cases and controls, previous episodes of MA-ILI related to $\mathrm{A}\left(\mathrm{H}_{1} \mathrm{~N}_{1}\right)$ pdmog virus were $63 \%(95 \% \mathrm{Cl}: 16-84)$ protective against laboratory-confirmed $\mathrm{A}\left(\mathrm{H}_{1} \mathrm{~N}_{1}\right)$ pdmo9 influenza, even though the natural exposure had in most cases occurred more than two years before. The protective effect was similar in the analysis restricted to patients attended in primary healthcare and to those younger than 65 years. One case without comorbidity that had been confirmed with influenza $\mathrm{A}\left(\mathrm{H}_{1} \mathrm{~N}_{1}\right)$ pdmo9 in the $2009 / 10$ season was again confirmed with influenza from the same virus subtype in the $2013 / 14$ season. In the same models, the overall adjusted VE was 
$45 \%$ (95\% Cl: $12-65)$, and similar estimates of the VE were found in the analysis stratified by age group or healthcare setting (Table 4).

The comparison of influenza $\mathrm{A}\left(\mathrm{H}_{3} \mathrm{~N}_{2}\right)$ cases and controls showed that previous episodes of MA-ILI related to $\mathrm{A}\left(\mathrm{H}_{3} \mathrm{~N}_{2}\right)$ virus were $65 \%(95 \% \mathrm{Cl}: 13-86)$ protective against laboratory-confirmed influenza $A\left(\mathrm{H}_{3} \mathrm{~N}_{2}\right)$ and $70 \%(95 \% \mathrm{Cl}: 15-90)$ protective in the analysis restricted to patients younger than 65 years. On the other hand, the overall adjusted VE was $20 \%(95 \% \mathrm{Cl}$ : -15 to 45 ), and other estimates of the VE for subgroups of patients were also low and not statistically significant (Table 4). In most cases, the natural exposure had occurred more than a year before.

Minor differences in the VE estimates were seen in the sensitivity analysis performed after excluding the variable of previous MA-ILI from the model. The overall estimate of the influenza VE was 31\% (95\% Cl: 5-50) against any laboratory-confirmed influenza, 45\% (95\% $\mathrm{Cl}: 12-65)$ against influenza $\mathrm{A}\left(\mathrm{H}_{1} \mathrm{~N}_{1}\right)$ pdmog, and $20 \%$ (95\% Cl: -16 to 44 ) in preventing influenza $A\left(\mathrm{H}_{3} \mathrm{~N}_{2}\right)$ cases. The same estimates after excluding from the analysis the patients with previous MA-ILI that was probably related to influenza were $33 \%(95 \% \mathrm{Cl}: 6-52)$, $48 \%(95 \% \mathrm{Cl}: 27-68)$ and $19 \%(95 \% \mathrm{Cl}:-18$ to 44$)$, respectively.

The sensitivity analysis excluding vaccinated patients also showed similar protective effects of previous episodes of MA-ILI probably related to influenza: $32 \%$ (95\% Cl: -8 to 58$)$ for any influenza, $77 \%(95 \% \mathrm{Cl}$ : 40-91) for influenza $A\left(\mathrm{H}_{1} \mathrm{~N}_{1}\right)$ pdmog and $63 \%(95 \% \mathrm{Cl}$ : -3 to 86$)$ for influenza $A\left(\mathrm{H}_{3} \mathrm{~N}_{2}\right)$.

\section{Discussion}

In this study we estimated at the same time the protection conferred by previous episodes of MA-ILI and by influenza vaccination in a season with intense cocirculation of influenza $A\left(\mathrm{H}_{1} \mathrm{~N}_{1}\right)$ pdmog and $A\left(\mathrm{H}_{3} \mathrm{~N}_{2}\right)$. People with a history of MA-ILI attributable to a specific virus subtype in the previous five seasons had a markedly lower risk of disease due to the same subtype. The trivalent inactivated vaccine showed moderate VE in preventing laboratory-confirmed influenza $A\left(H_{1} N_{1}\right) p d m o g$ and low effectiveness against influenza $\mathrm{A}\left(\mathrm{H}_{3} \mathrm{~N}_{2}\right)$. Even though the natural exposure had in most cases occurred more than a year before, it conferred the same or greater protection against the same virus subtype than the vaccine administered a few months previously. In accordance with McLean et al., five previous seasons were considered for natural protection [14] because the protection following natural exposure is stronger and longer-lasting and covers a greater variety of viral strains, which has been related to activation of a more complete immune response that includes mechanisms of cellular immunity $[4,15,16]$. No major shift had affected the circulating viruses involved in the analysis.
It was possible to define the virus that most probably caused the cases of MA-ILI in the previous five seasons thanks to the fact that one virus clearly predominated in Navarre in each of those five seasons. In seasons with simultaneous co-circulation of various viruses, it would be more difficult to attribute the cases of MA-ILI with certainty to a specific virus subtype.

Since the appearance of the $\mathrm{A}\left(\mathrm{H}_{1} \mathrm{~N}_{1}\right)$ pdmog virus in 2009, the circulating strains of this virus have been well matched with the vaccine strain $A /$ California/7/2009( $\left.\mathrm{H}_{1} \mathrm{~N}_{1}\right)$ [2], which could explain the protection of the vaccine and of influenza episodes in previous seasons.

Although the influenza $A\left(\mathrm{H}_{3} \mathrm{~N}_{2}\right)$ virus strains which circulated in the 2013/14 season had a good genetic match with the vaccine strain [2], the observed VE was low. However, this virus showed a high cross protection with the strains circulating in the previous seasons 2008/09 and 2011/12. This difference between natural and vaccine protection with matched strains should encourage the exploration of alternative ways of obtaining better vaccines against influenza.

In the study population, natural and vaccine immunity were distributed in a complementary manner. A history of MA-ILI was more frequent in persons aged five to 44 years, which explains why this protective mechanism was more important in population groups that do not normally get vaccinated against influenza.

Although previous diagnosis of disease from the same virus subtype was associated with high protection, previous MA-ILI related to any influenza virus but not restricted to the same virus subtype conferred only low protection against a new episode of laboratoryconfirmed influenza. This is mainly explained by the likelihood of infection by a different type or subtype of influenza virus. Therefore, in persons with risk factors for influenza complications, having had the disease in previous seasons should not be a reason not to get vaccinated. While natural exposure protects specifically against the virus subtype to which one has been exposed, the protection conferred by the trivalent vaccine, although less strong, covers all three virus types/ subtypes simultaneously.

Previous episodes of influenza are not usually taken into account as potential confounding factors in studies evaluating influenza VE. To our knowledge, only McLean et al. had adjusted for influenza diagnoses in the prior five seasons in the analysis of influenza vaccine effectiveness [14]. In this and in our study, the estimated VE did not change regardless of whether the models included this history, suggesting that this variable does not act as a confounding factor that needs to be controlled.

Although our end-of-season estimate of VE was additionally adjusted for previous episodes of influenza, 
it was consistent with mid-season estimates obtained in Navarre and Spain for this same season $[17,18]$, and with estimates obtained at the end of the season in a European multicentre study and in Greece $[19,20]$; it was less consistent, however, with estimates from other countries with different distribution of virus types, subtypes and strains detected in the same season [21-23].

Some limitations should be considered in interpreting the results of this study. Previous episodes of MA-ILI reflect the history of exposures to the influenza virus from the healthcare perspective and may be considered a proxy for natural immunity. Some $10 \%$ of subjects included in the study had a history of MA-ILI in the previous five seasons. However, the proportion of the population with natural immunity against influenza could be considerably higher, since it is estimated that 30-50\% of influenza infections are asymptomatic [24]. In one study conducted in Navarre, $36 \%$ of symptomatic cases had not sought medical care [25]. It should also be added that there is possible immunity from exposures occurring more than five years previously. This misclassification in the previous influenza infection is probably non-differential and would bias the estimates towards the null effect. In the absence of this bias, the protection due to previous episodes would have been higher.

Of the patients with a previous episode of MA-ILI, only $17 \%$ had a laboratory-confirmed diagnosis, while the rest met only one epidemiological criterion for the disease. Based on the percentage of swabs confirmed for influenza in each season (Table 1), we estimate that this criterion ensures the correct classification of $70 \%$ of cases with a history of influenza $A\left(\mathrm{H}_{3} \mathrm{~N}_{2}\right)$, of over $50 \%$ of cases with a history of influenza $A\left(\mathrm{H}_{1} \mathrm{~N}_{1}\right)$ pdmog, and of $64 \%$ of cases with a history of any influenza in the previous five years. Accordingly, we cannot totally rule out the possibility of incorrect classification that arose from considering cases that could have been due to another cause such as previous episodes related to a specific virus. If we had had laboratory confirmation of all the cases of influenza in previous years, the protective effect of this history would probably have been greater.

The results presented had limited statistical power for some analyses, mainly because of the low numbers of cases and controls with previous MA-ILI included in the study. Laboratory-confirmed cases were compared with controls recruited in the same healthcare settings before either patient or physician knew the laboratory result, a fact that reduced selection bias [26].

This study included MA-ILI patients recruited from the same population in both primary healthcare centres and hospitals. The healthcare setting could have acted as a confounding factor, therefore the analyses were adjusted for this variable. The possibility that the healthcare setting might have modified the effect or biased the results can be ruled out given the consistency of the estimates obtained in these two patient groups and in the joint analysis. The joint analysis achieved representation of the whole spectrum of patients with influenza in the population.

\section{Conclusion}

Our results suggest low to moderate influenza VE in the $2013 / 14$ season, which prevented almost a third of the influenza cases and hospitalisations in the vaccinated population; while not entirely satisfactory, this result is important in terms of individual and public health. Previous influenza episodes were highly effective against new influenza illness by the same virus subtype, and this effect seemed to persist over various seasons, which may point to possible avenues of obtaining better vaccines against influenza. In any case, annual influenza vaccination remains the principal preventive option in persons at high risk of developing complications if they contract influenza.

The members of the Primary Health Care Sentinel Network of Navarra are

I Abad, P Aldaz, E Álvarez, N Alvarez, JJ Arana, I Arceiz, E Arina, I Arribas, MD Artajo, B Azagra, FC Bartolome, C Bolea, A Brugos, B Cano, MV Castresana, JC Cenoz, F Cia, B Compains, F Cortés, B Churío, PC Cuevas, EM Da Costa, J Díez Espino, M Doiz, FJ Escribano, MJ Esparza, V Etayo, C Fernández Alfaro, B Flamarique, J Gamboa, ML Garcés, L García Blanco, AB German, A Giner, N Goñi, MJ Guillorme, JO Guiu, JC Gurbindo, MJ Guruchaga, JA Heras, MC Hijos, J Huidobro, S Indurain, B Iñigo, MC Irigoyen, JJ Jurio, MP León, JJ Longás, MJ López, MT Maquirriain, JJ Miner, M Moreno, MA Moros, U Navarro, FJ Orozco, M Orte, P Palacio, J Palau, C Pérez Lecumberri, P Pérez Pascual, B Pérez Sanz, A Prado, M Prado, A Puig, E Ridruejo, M Ramos, BE Rípodas, M Rodríguez, MA Roncal, I Ruiz Puertas, C Sánchez, P Sarrasqueta, MA Senosiain, J Sola, M Sota, ME Ursua, IA Urtasun, MJ Vigata, MT Virto.

The members of the Network for Influenza Surveillance in Hospitals of Navarra are

P Artajo, X Beristain, E Bernaola, J Chamorro, M Esquiroz, C Ezpeleta, P Fanlo, F Gil, M Gabari, J Hueto, C Martín, A Navascués, L Peña, C Pérez, I Polo, M Ruiz, N Viguria (Complejo Hospitalario de Navarra), M Fernández-Alonso, J Nuñez (Clínica Universidad de Navarra), JJ García Irure, M Ortega, M Torres (Hospital Reina Sofía, Tudela), F Lameiro, L Barrado (Hospital García Orcoyen, Estella), N Álvarez (Servicio Navarro de Salud), A Zabala, M García Cenoz, F Irisarri, M Arriazu, A Barricarte, J Castilla (Instituto de Salud Pública de Navarra).

\section{Acknowledgements}

This work was supported by the I-MOVE (Influenza Monitoring Vaccine Effectiveness in Europe) Network funded by the European Centre for Disease Prevention and Control (ECDC), by the Carlos III Institute of Health with the European Regional Development Fund (ERDF) (PI12/00087) and by the Spanish Ministry of Health (EC11-302). 
Conflict of interest

None declared.

\section{Authors' contributions}

J Castilla, I Martínez-Baz and M Guevara designed the study, coordinated the activities, and undertook the statistical analysis. A Navascués, M Fernández-Alonso, G Reina and C Ezpeleta were responsible of the virological analysis and the interpretation of laboratory results. M García Cenoz, N Álvarez, F Irisarri and I Casado participated in the data collection. E Albéniz coordinated the activities in primary health care. F Pozo was responsible for the virus characterizations. J Castilla, M Guevara and I Martínez-Baz wrote the draft manuscript, and all authors revised and approved the final version.

\section{References}

1. World Health Organization (WHO). Fact sheet No 211. Influenza (seasonal). Geneva: WHO; April 2009. Available from: http:// www.who.int/mediacentre/factsheets/fs211/en/index.html

2. European Centre for Disease Prevention and Control (ECDC). Influenza virus characterization. Surveillance report. Stockholm: ECDC; December 2013. Available from: http:// www.ecdc.europa.eu/en/healthtopics/seasonal_influenza/ epidemiological_data/Pages/Influenza_virus_characterisation. aspx

3. Sauerbrei A, Langenhan T, Brandstadt A, Schmidt-Ott R, Krumbholz A, Girschick H, et al. Prevalence of antibodies against influenza $A$ and $B$ viruses in children in Germany, 2008 to 2010. Euro Surveill. 2014;19(5):20687. DOI: 10.2807/15607917.ES2014.19.5.20687 PMID: 24524235

4. Ohmit SE, Petrie JG, Cross RT, Johnson E, Monto AS. Influenza hemagglutination-inhibition antibody titer as a correlate of vaccine-induced protection.J Infect Dis. 2011;204(12):1879-85. DOI: 10.1093/infdis/jir661 PMID: 21998477

5. Epstein SL, Lo CY, Misplon JA, Bennink JR. Mechanism of protective immunity against influenza virus infection in mice without antibodies.J Immunol. 1998;160(1):322-7.PMID: 9551987

6. Recommended composition of influenza virus vaccines for use in the 2013-2014 northern hemisphere influenza season. Wkly Epidemiol Rec. 2013;88(10):101-14.PMID: 23544236

7. Adlhoch C, Broberg E, Beauté J, Snacken R, Bancroft E, Zucs P, et al. Influenza season 2013/14 has started in Europe with influenza $\mathrm{A}\left(\mathrm{H}_{1}\right)$ pdmog virus being the most prevalent subtype. Euro Surveill. 2014;19(4):20686. DOI: 10.2807/1560-7917. ES2014.19.4.20686 PMID: 24507465

8. Sistema de Vigilancia de la Gripe en España. Informe semanal 4/2014. [Report of the influenza surveillance system in Spain 4/2014]. Madrid: Instituto de Salud Carlos III; 30 January 2014. $\mathrm{N}^{\circ}$ 378. Spanish. Available from: http://vgripe.isciii.es/gripe/ documentos/20132014/boletines/grno42014.pdf

9. European Centre for Disease Prevention and Control. Weekly influenza surveillance overview. 31 January 2014. Available from: http://www.ecdc.europa.eu/en/publications/ Publications/influenza-surveillance-overview-31-jan-2014.pdf

10. Hoskins TW, Davies JR, Smith AJ, Miller CL, Allchin A. Assessment of inactivated influenza-A vaccine after three outbreaks of influenza A at Christ's Hospital.Lancet. 1979;1(8106):33-5. DOI: 10.1016/S0140-6736(79)90468-9 PMID: 83475

11. Davies JR, Grilli EA. Natural or vaccine-induced antibody as a predictor of immunity in the face of natural challenge with influenza viruses. Epidemiol Infect. 1989;102(2):325-33. DOI: 10.1017/So950268800030004 PMID: 2703026

12. Instituto de Salud Pública y Laboral de Navarra. Protocolo de vacunación antigripal 2013-2014 [Influenza vaccination protocol 2013-2014]. Boletín Informativo. 2013;74. Spanish. Available from: http://www.navarra.es/NR/rdonlyres/ AECCD760-AB2A-4841-818A-FA53478FD6DC/275548/ BOL74INTCampana20132014 ModificadoFeb2014.pdf

13. Aguilar I, Reyes M, Martínez-Baz I, Guevara M, Albéniz E, Belza $M$, et al. Use of the vaccination register to evaluate influenza vaccine coverage in seniors in the 2010/11 influenza season, Navarre, Spain. Euro Surveill. 2012;17(17):20154.PMID: 22551499

14. McLean HQ, Thompson MG, Sundaram ME, Meece JK, McClure DL, Friedrich TC, et al. Impact of repeated vaccination on vaccine effectiveness against influenza $A\left(\mathrm{H}_{3} \mathrm{~N}_{2}\right)$ and $B$ during 8 seasons. Clin Infect Dis. 2014:59(10):1375-85. DOI: $10.1093 / \mathrm{cid} /$ ciu680 PMID: 25270645

15. Wei CJ, Yassine HM, McTamney PM, Gall JG, Whittle JR, Boyington JC, et al. Elicitation of broadly neutralizing influenza antibodies in animals with previous influenza exposure. Sci Transl Med. 2012;4(147):147ra114.13.

16. He XS, Holmes TH, Sanyal M, Albrecht RA, García-Sastre A, Dekker CL, et al. Distinct patterns of B-cell activation and priming by natural influenza virus infection versus inactivated influenza vaccination. J Infect Dis. 2015;211(7):1051-9. DOI: 10.1093/infdis/jiu580 PMID: 25336731

17. Castilla J, Martínez-Baz I, Navascués A, Fernandez-Alonso M, Reina $G$, Guevara $M$, et al. Vaccine effectiveness in preventing laboratory-confirmed influenza in Navarre, Spain: 2013/14 mid-season analysis. Euro Surveill. 2014;19(6):20700. DOI: 10.2807/1560-7917.ES2014.19.6.20700 PMID: 24556347

18. Jimnez-Jorge S, Pozo F, de Mateo S, Delgado-Sanz C, Casas I, Garcia-Cenoz M, et al. Influenza vaccine effectiveness in Spain 2013/14: subtype-specific early estimates using the cycEVA study. Euro Surveill. 2014;19(9):20727. DOI: 10.2807/1560-7917.ES2014.19.9.20727 PMID: 24626206

19. Valenciano $M$, Kissling E, Reuss A, Jiménez-Jorge S, Horváth JK, Donnell JM, et al. The European I-MOVE Multicentre 2013-2014 Case-Control Study. Homogeneous moderate influenza vaccine effectiveness against $A\left(\mathrm{H}_{1} \mathrm{~N}_{1}\right)$ pdmog and heterogenous results by country against $A\left(\mathrm{H}_{3} \mathrm{~N}_{2}\right)$. Vaccine. 2015;33(24):2813-22. DOI: 10.1016/j.vaccine.2015.04.012 PMID: 25936723

20. Lytras T, Kossyvakis A, Melidou A, Exindari M, Gioula G, Pogka $\mathrm{V}$, et al. Influenza vaccine effectiveness against laboratory confirmed influenza in Greece during the 2013-2014 season: a test-negative study. Vaccine. 2015;33(2):367-73. DOI: 10.1016/j. vaccine.2014.11.005 PMID: 25448097

21. Turner N, Pierse N, Bissielo A, Huang Q, Radke S, Baker $M$, et al. Effectiveness of seasonal trivalent inactivated influenza vaccine in preventing influenza hospitalisations and primary care visits in Auckland, New Zealand, in 2013. Euro Surveill. 2014;19(34):20884. DOI: 10.2807/1560-7917. ES2014.19.34.20884 PMID: 25188614

22. McNeil S, Shinde V, Andrew M, Hatchette T, Leblanc J, Ambrose A, et al. Interim estimates of 2013/14 influenza clinical severity and vaccine effectiveness in the prevention of laboratory-confirmed influenza-related hospitalisation, Canada, February 2014. Euro Surveill. 2014;19(9):20729. DOI: 10.2807/1560-7917.ES2014.19.9.20729 PMID: 24626207

23. Skowronski D, Chambers C, Sabaiduc S, De Serres G, Dickinson J, Winter A, et al. Interim estimates of 2013/14 vaccine effectiveness against influenza $A\left(\mathrm{H}_{1} \mathrm{~N}_{1}\right)$ pdmog from Canada s sentinel surveillance network, January 2014. Euro Surveill. 2014;19(5):20690. DOI: 10.2807/1560-7917. ES2014.19.5.20690 PMID: 24524234

24. Wilde JA, McMillan JA, Serwint J, Butta J, O'Riordan MA, Steinhoff MC. Effectiveness of influenza vaccine in health care professionals: a randomized trial.JAMA. 1999;281(10):908-13. DOI: 10.1001/jama.281.10.908 PMID: 10078487

25. Burgui R, Martínez-Baz I, Guevara M, Carlos S, Castilla J. Use of medical care during pandemic $\left(\mathrm{H}_{1} \mathrm{~N}_{1}\right) 2009$, Navarre, Spain. Emerg Infect Dis. 2011;17(8):1463-6.PMID: 21801624

26. Valenciano M, Kissling E, Ciancio BC, Moren A. Study designs for timely estimation of influenza vaccine effectiveness using European sentinel practitioner networks.Vaccine. 2010;28(46):7381-8. DOI: 10.1016/j.vaccine.2010.09.010 PMID: 20851086

\section{License and copyright}

This is an open-access article distributed under the terms of the Creative Commons Attribution (CC BY 4.0) Licence. You may share and adapt the material, but must give appropriate credit to the source, provide a link to the licence, and indicate if changes were made.

This article is copyright of the authors, 2016. 